\title{
ANALYSIS OF GANGLION CELL COMPLEX AND RETINAL NERVE FIBER LAYER THICKNESS IN GLAUCOMA DIAGNOSIS
}

\author{
Sania Vidas ${ }^{1}$, Smiljka Popović-Suić ${ }^{1,2}$, Katia Novak Lauš, Sonja Jandroković ${ }^{1}$, \\ Martina Tomić ${ }^{4}$,Tomislav Jukić ${ }^{1,2}$ and Miro Kalauz ${ }^{1,2}$
}

${ }^{1}$ Clinical Department of Ophthalmology, Zagreb University Hospital Center; ${ }^{2}$ University of Zagreb, School of Medicine, Zagreb, Croatia; ${ }^{3}$ Clinical Department of Ophthalmology, Sestre milosrdnice

University Hospital Center, Zagreb, Croatia; ${ }^{4}$ Vuk Vrhovac University Clinic for Diabetes, Endocrinology and Metabolic Diseases, Merkur University Hospital, Zagreb, Croatia

SUMMARY - The aim was to compare retinal nerve fiber layer (RNFL) and ganglion cell complex (GCC) thicknesses in patients with primary open angle glaucoma (POAG), ocular hypertension $(\mathrm{OH})$ and healthy subjects, and to investigate the role of GCC parameters in glaucoma diagnosis. Eighty-one patients were divided into four groups according to Hodapp-Parrish-Anderson classification: $26 \mathrm{OH}, 22$ early POAG, 10 moderate to advanced POAG, and 23 healthy subjects. All patients underwent RNFL and GCC thickness measurement using SOCT Copernicus HR. All RNFL and GCC parameters were significantly lower in POAG than in $\mathrm{OH}$ and healthy subjects, especially Average RNFL, RNFL Superior and Inferior, GCC Average, and GGC Inferior. Of all RNFL parameters, the highest area under the receiver operating characteristic curve (AUC) was recorded for Average RNFL, 0.906. GCC Average, and GCC Superior and Inferior had the overall highest AUCs (0.957, 0.955 and 0.946 , respectively) with 100\% specificity. The RNFL Average and Inferior and GCC Average, Superior and Inferior were identified as the main predictors for development of glaucoma $(\mathrm{p}=0.015$ and $\mathrm{p}=0.014$ vs. $\mathrm{p}=0.002, \mathrm{p}=0.002$ and $\mathrm{p}=0.003$, respectively). In conclusion, GCC parameters showed a slightly better glaucoma discriminating ability and were found to be better predictors for development of glaucoma as compared with RNFL.

Key words: Glaucoma; Nerve fibers; Glaucoma, open angle; Glaucoma, primary open angle; Ocular bypertension; Croatia

\section{Introduction}

Glaucoma is an optic neuropathy characterized by death of retinal ganglion cells and their respective axons, corresponding to retinal nerve fiber layer (RNFL) loss and optic nerve head $(\mathrm{ONH})$ cupping $^{1}$. It is known that detectable structural abnormality may precede functional abnormality in some patients. The exact nature of the 'structure-function' relationship in primary

Correspondence to: Sania Vidas, MD, Clinical Department of Ophthalmology, Zagreb University Hospital Centre, Kišpatićeva 12, HR-10000, Zagreb, Croatia

E-mail: sania_vidas@yahoo.com

Received January 20, 2017, accepted February 28, 2017 open-angle glaucoma (POAG) is still a topic of scientific debate and subject of continuous research ${ }^{2}$. However, most studies suggest that death of ganglion cells is associated with structural and functional changes ${ }^{2,3}$. A large part of ganglion cells are located in macular region, which makes this area of special interest for glaucoma investigation ${ }^{4}$.

In recent years, the focus of research in the field of glaucoma has been directed to finding a more accurate method for earlier glaucoma detection. Time-domain optical coherence tomography (TD-OCT) has previously shown usefulness of peripapillary RNFL thickness measurement in glaucoma diagnosis, so RNFL 
has become a proven and widely used parameter for evaluation of glaucoma in routine clinical practice ${ }^{5-7}$. Macular thickness measurement using TD-OCT has not been nearly as accurate parameter as $\mathrm{RNFL}^{8}$. In the last 10-15 years, the advent of spectral-domain optical coherence tomography (SD-OCT) has improved monitoring of the macular region providing its segmentation. This has allowed identification of each lay$\mathrm{er}^{9-11}$. The layers that become thinner in glaucoma are the inner three retinal layers, i.e. the inner plexiform layer including dendrites, the bodies and the RNFL (axons) of ganglion cells. These three layers form the ganglion cell complex (GCC). It is believed that the earliest changes are seen as a loss of dendritic arbor and subsequently death of retinal ganglion cell bodies, so GCC presents the earliest parameter being changed in glaucoma ${ }^{12}$.

Nowadays, wide application of SD-OCT has made GCC assessment more accessible. Many studies investigated its role in early and preperimetric glaucoma detection, presenting it as a promising tool for identifying structural, especially early glaucoma damage. However, some studies failed to show GCC superiority over RNFL, presenting both methods as complementary ${ }^{13-23}$. The role of GCC in glaucoma diagnosis has not yet been completely defined and results of studies more or less differ. Our objective was to analyze structural parameters obtained by SOCT Copernicus HR in glaucoma detection, since we use it routinely in our clinical practice.

The aim of this study was to compare RNFL and GCC thickness in patients with POAG, ocular hypertension and healthy subjects, and to investigate the role of GCC parameters in glaucoma diagnosis.

\section{Patients and Methods}

This cross-sectional nonintervention study was conducted at the Clinical Department of Ophthalmology, Zagreb University Hospital Center, Zagreb, Croatia. A total of 81 subjects, who consecutively attended General Ophthalmology Dispensary and Glaucoma Division over a three-month period, were included. All patients underwent complete ophthalmological examination including best corrected visual acuity (BCVA), Goldmann applanation tonometry, slit lamp biomicroscopy of the anterior eye segment, goni- oscopy, binocular indirect slit lamp funduscopy for evaluation of $\mathrm{ONH}$ after $0.5 \%$ tropicamide mydriasis, visual field (VF) testing, and OCT. The inclusion criteria were BCVA at least 0.7 with spherical refractive error between +4.00 and -4.00 diopters and open angle on gonioscopy. The exclusion (non-inclusion) criteria were angle-closure glaucoma, non-glaucomatous optic neuropathies, moderate and advanced cataract, retinal and macular pathology, previous ocular surgery, retinal laser procedure, or trauma. Patients with diabetes, malignancies, immune, infectious and neurologic diseases, patients receiving corticosteroids or cytostatics, and pregnant women were not included in the study. The study protocol was approved by the institutional Ethics Committee and was performed in adherence with the guidelines of the Declaration of Helsinki. The patients received both written and oral information about the study and signed a written informed consent.

Visual field testing was performed with static automated white-on-white perimetry (Octopus 900, G2 normal program 32, Haag-Streit, Switzerland) and confirmed with at least two examinations. VF was defined as reliable when fixation losses were $<20 \%$, reliability factor $<15 \%$, false positive rates $<20 \%$, and false negative rates $<25 \%$. A VF defect was defined as glaucomatous with the presence of at least three or more significant $(p<0.05)$, contiguous nonedge points in clusters with one point at $\mathrm{p}<0.01$ level at the same side of horizontal meridian in the corrected probabilities plot $^{24}$. The Hodapp-Parrish-Anderson classification scheme was used to grade glaucomatous lesions ${ }^{24}$. In each patient, the 'worse' eye was graded for glaucoma using VF defect.

Spectral-domain optical coherence tomography was performed with SOCT Copernicus HR (Optopol Technology, Poland) with axial resolution of $3 \mu \mathrm{m}$ in tissue, transverse resolution $12-18 \mu \mathrm{m}$, speed 52000 A-scans/s, scanning density $2000 \mathrm{~A}$-scans/mm, and wavelength $850 \mathrm{~nm}$. Minimum acceptable signal strength was 6. RNFL and GCC scanning were analyzed and obtained by the same educated examiner. The examiner was masked to the VF and clinical findings.

The protocol for $\mathrm{ONH}$ was created for the evaluation of RNFL and ONH. The tomograph makes normally 75-90 disc scans. Circular scans were made around the $\mathrm{ONH}$ with diameter from 1.0 to $5.0 \mathrm{~mm}$ 
and after analysis, a RNFL map was constructed. After that, 13-30 radial scans were made to determine the boundaries of $\mathrm{ONH}$ and its structural variables. This program automatically determined the center of the $\mathrm{ONH}$ and its borders. We analyzed and compared $\mathrm{Av}^{-}$ erage RNFL, and four RNFL quadrants, i.e. Temporal, Superior, Nasal and Inferior, and temporal-superior-nasal-inferior-temporal quadrants (TSNIT) curve.

The protocol for GCC measures thickness of the three inner layers of the retina in the macular region. It takes $1.7 \mathrm{~s}$ and covers the area of $7 \mathrm{~mm}^{2}$. The analyzed variables from the GCC map in this study were GCC Average (average GCC thickness for the whole area), GCC Superior (average GCC thickness for the superior half of the area), GCC Inferior (average GCC thickness for the inferior half of the area), and GCC Minimum (minimum GCC thickness for the whole area). The whole area except for central $1 \mathrm{~mm}$ was divided into six GCC sectors (superotemporal, superior, superonasal, inferonasal, inferior and inferotemporal) clockwise on the right eye and other clockwise on the left eye (Fig. 1).

Study subjects were divided into four groups: group 1, patients with $\mathrm{OH}(\mathrm{n}=26)$; group 2, patients with early POAG $(\mathrm{n}=22)$; group 3 , patients with moderate to advanced POAG ( $\mathrm{n}=10)$; and control group of healthy subjects $(n=23)$. Patients with $\mathrm{OH}$ had intraocular pressure (IOP) between 21 and $30 \mathrm{~mm} \mathrm{Hg}$ on at least three separate measurements, normal VF and normal ONH appearance. Patients with early POAG had characteristic glaucomatous optic neuropathy with corresponding VF loss and VF mean deviation index better than $6 \mathrm{~dB}$, according to Hodapp-Parrish-Anderson classification. Third group were patients with moderate to advanced POAG according to HodappParrish-Anderson classification. Control group consisted of healthy subjects with no history of IOP $>21$ $\mathrm{mm} \mathrm{Hg}$, with completely normal VF and $\mathrm{ONH}$ appearance. Patients with abnormal disc appearance and normal VFs were not included in the study.

Statistical analysis was performed using Statistica software package version 12 (StatSoft, Inc., Tulsa, OK, USA) and SPSS software package version 24.0 (IBM, Armonk, NY, USA). Results were presented as mean \pm $\mathrm{SD}$, median (min-max), and percentages. Differences in distributions of continuous data were determined by ANOVA test. Differences in distributions of categorical data were evaluated by $\chi^{2}$-test. The sensitivity and

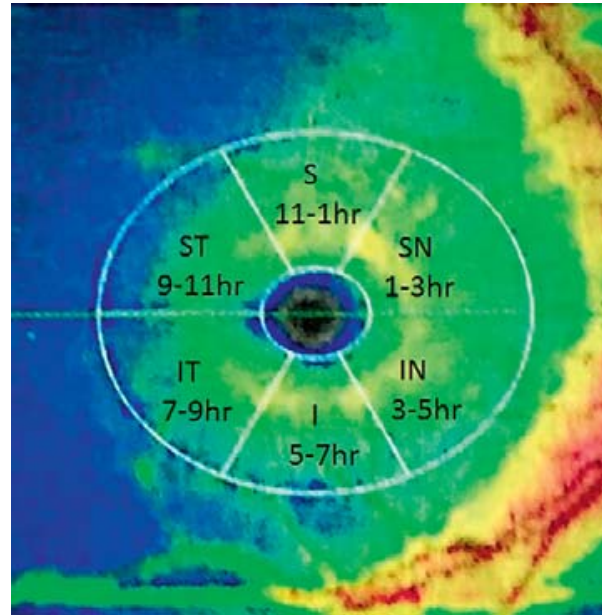

Fig. 1. Ganglion cell complex (GCC) map of the right eye. Whole area except for central $1 \mathrm{~mm}$ is divided into six GCC sectors clockwise: superotemporal (ST), superior (S), superonasal (SN), inferonasal (IN), inferior (I) and inferotemporal (IT).

specificity were calculated and area under the ROC curve (AUC) was used to assess the ability to differentiate glaucomatous eyes from non-glaucomatous eyes with each testing parameter. An AUC of 1.0 represents perfect discrimination, whereas an area of 0.5 represents chance discrimination. Logistic regression analysis was used to assess the strength and independence of associations. The value of $\mathrm{p}<0.05$ was considered statistically significant.

\section{Results}

This study included 81 subjects (29 male and 52 female), mean age $56.60 \pm 11.08$ years. The mean BCVA was $0.96 \pm 0.09$, median spherical refraction +0.50 $(-3.00,+3.75)$ and mean IOP $17.54 \pm 5.10 \mathrm{~mm} \mathrm{Hg}$. Subjects were divided into four groups, as follows: 26 patients with $\mathrm{OH}$ (group 1, mean age 52.46 \pm 10.89 years); 22 patients with early POAG (group 2, mean age $62.73 \pm 6.78$ years); 10 patients with moderate to advanced POAG (group 3, mean age 67.11 \pm 6.69 years); and 23 healthy subjects (control group, mean age $51.30 \pm 10.64$ years). There were no differences according to sex, refraction or BCVA among study groups ( $\mathrm{p}=0.706 ; \mathrm{p}=0.401)$. Mean defect $(\mathrm{MD})$ and loss variance $(\mathrm{LV})$ were significantly higher in patients with glaucoma (groups 2 and 3 ) than in healthy subjects and patients with $\mathrm{OH}(\mathrm{p}<0.001$ both) (Table 1). 
Table 1. Baseline and ophthalmologic characteristics of study subjects $(N=81)$

\begin{tabular}{|l|l|l|l|l|l|l|}
\hline & $\begin{array}{l}\text { OH } \\
(\mathrm{n}=26)\end{array}$ & $\begin{array}{l}\text { Early POAG } \\
(\mathrm{n}=22)\end{array}$ & $\begin{array}{l}\text { Moderate to } \\
\text { advanced POAG } \\
(\mathrm{n}=10)\end{array}$ & $\begin{array}{l}\text { Controls } \\
(\mathrm{n}=23)\end{array}$ & $\mathrm{F}^{\mathrm{a}} \boldsymbol{\chi}^{-\mathrm{b}}$ & $\mathrm{p}$ \\
\hline Age (years)* & $52.46 \pm 10.89$ & $62.73 \pm 6.78$ & $67.11 \pm 6.69$ & $51.30 \pm 10.64$ & $10.871^{\mathrm{a}}$ & $<\mathbf{0 . 0 0 1}^{\mathrm{a}}$ \\
Sex (m/f)** & $38 / 62$ & $32 / 68$ & $50 / 50$ & $30 / 70$ & $1.397^{\mathrm{b}}$ & $0.706^{\mathrm{b}}$ \\
BCVA (decimal)* & $0.98 \pm 0.06$ & $0.94 \pm 0.10$ & $0.88 \pm 0.12$ & $0.98 \pm 0.07$ & $4.218^{\mathrm{a}}$ & $\mathbf{0 . 0 0 8}^{\mathrm{a}}$ \\
Refraction (decimal)*** & +0.50 & 0.00 & 0.00 & 0.00 & $0.992^{\mathrm{a}}$ & $0.401^{\mathrm{a}}$ \\
IOP (mm Hg)* & $(-2.75,+3.75)$ & $(-3.00,+3.00)$ & $(-1.75,+2.50)$ & $(-3.0,+2.0)$ & $5.522^{\mathrm{a}}$ & $\mathbf{0 . 0 0 2}^{\mathrm{a}}$ \\
MD (dB)* & $18.46 \pm 3.90$ & $18.77 \pm 5.02$ & $20.22 \pm 9.46$ & $14.26 \pm 1.66$ & $78.297^{\mathrm{a}}$ & $<\mathbf{0 . 0 0 1}^{\mathrm{a}}$ \\
$\mathrm{LV}^{*}$ & $0.62 \pm 0.99$ & $3.15 \pm 1.46$ & $12.90 \pm 6.12$ & $0.40 \pm 0.71$ & $137.52^{\mathrm{a}}$ & $<\mathbf{0 . 0 0 1}^{\mathrm{a}}$ \\
\hline
\end{tabular}

*mean $\pm \mathrm{SD} ;{ }^{* *}$ percentage; ***median (min, max); ${ }^{2} \mathrm{ANOVA} \mathrm{df}=3$; ${ }^{\mathrm{b}} \chi^{2}$-test $\mathrm{df}=3 ; \mathrm{OH}=$ ocular hypertension; POAG = primary open angle glaucoma; $\mathrm{BCVA}=$ best corrected visual acuity; $\mathrm{IOP}=$ intraocular pressure; $\mathrm{MD}=$ mean defect; $\mathrm{LV}=$ loss variance

Table 2. RNFL Average and RNFL in TSNIT quadrants and clock hour sectors of study subjects ( $N=81)$

\begin{tabular}{|l|l|l|l|l|l|l|}
\hline & $\begin{array}{l}\text { OH } \\
(\mathrm{n}=26)\end{array}$ & $\begin{array}{l}\text { Early POAG } \\
(\mathrm{n}=22)\end{array}$ & $\begin{array}{l}\text { Moderate to } \\
\text { advanced POAG } \\
(\mathrm{n}=10)\end{array}$ & $\begin{array}{l}\text { Controls } \\
(\mathrm{n}=23)\end{array}$ & $\mathrm{F}$ & $\mathrm{p}$ \\
\hline RNFL Average $(\mu \mathrm{m})^{*}$ & $107.62 \pm 8.94$ & $97.09 \pm 9.33$ & $65.80 \pm 6.36$ & $115.52 \pm 7.85$ & 86.295 & $<\mathbf{0 . 0 0 1}$ \\
RNFL Temporal $(\mu \mathrm{m})^{*}$ & $63.69 \pm 9.01$ & $60.68 \pm 8.21$ & $53.00 \pm 13.23$ & $68.83 \pm 7.74$ & 7.738 & $\mathbf{0 . 0 0 1}$ \\
RNFL Superior $(\mu \mathrm{m})^{*}$ & $125.35 \pm 11.66$ & $112.23 \pm 13.98$ & $73.90 \pm 12.91$ & $135.74 \pm 14.23$ & 54.925 & $<\mathbf{0 . 0 0 1}$ \\
RNFL Nasal $(\mu \mathrm{m})^{*}$ & $78.50 \pm 11.37$ & $72.05 \pm 8.89$ & $63.60 \pm 17.65$ & $84.09 \pm 14.95$ & 7.179 & $\mathbf{0 . 0 0 2}$ \\
RNFL Inferior $(\mu \mathrm{m})^{*}$ & $124.92 \pm 13.59$ & $112.41 \pm 15.19$ & $64.00 \pm 9.68$ & $131.35 \pm 13.79$ & 61.657 & $<\mathbf{0 . 0 0 1}$ \\
\hline
\end{tabular}

*mean $\pm \mathrm{SD}, \mathrm{ANOVA}, \mathrm{df}=3 ; \mathrm{OH}=$ ocular hypertension; $\mathrm{POAG}=$ primary open angle glaucoma; RNFL = retinal nerve fiber layer; TSNIT $=$ temporal-superior-nasal-inferior-temporal quadrants

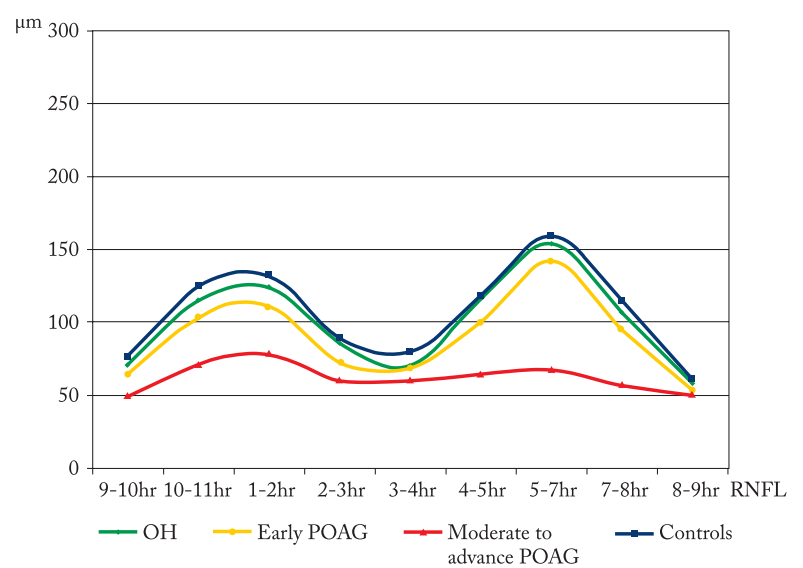

Fig. 2. Retinal nerve fiber layer (RNFL) curves in clock hour temporal-superior-nasal-inferior-temporal (TSNIT) sectors of study subjects $(N=81)$.

All RNFL parameters were significantly lower in glaucoma patients (groups 2 and 3) than in healthy subjects and patients with $\mathrm{OH}$, most significantly
RNFL Average $(p<0.001)$, RNFL Superior $(p<0.001)$ and RNFL Inferior ( $\mathrm{p}<0.001)$ (Table 2, Fig. 2).

All GCC parameters were significantly lower in glaucoma patients (groups 2 and 3 ) than in healthy subjects and patients with $\mathrm{OH}(\mathrm{p}<0.001)$, most significantly GCC Average $(\mathrm{F}=100.242 ; \mathrm{p}<0.001)$ and GCC Inferior ( $F=104.158$; $\mathrm{p}<0.001)$ (Table 3, Fig. 3).

The sensitivity of all RNFL and GCC parameters was high but not as excellent as their specificity in this study. The highest sensitivity (71.88\%) and specificity (100\%) was observed for GCC Superior. GCC Average, Superior and Inferior showed higher AUC than RNFL Average, Superior and Inferior, which emphasized higher diagnostic accuracy of GCC than RNFL parameters in glaucoma. The highest AUC had GCC Average and GCC Superior (Table 4, Fig. 4).

Logistic regression analysis showed that IOP, RNFL Average, RNFL Superior, GCC Average, GCC Superior and GCC Inferior were the main predictors 
Table 3. GCC Average, Superior, Inferior and Minimum, and GCC in TSNIT clock hour sectors of study subjects $(N=81)$

\begin{tabular}{|c|c|c|c|c|c|c|}
\hline & $\begin{array}{l}\mathrm{OH} \\
(\mathrm{n}=26)\end{array}$ & $\begin{array}{l}\text { Early POAG } \\
(\mathrm{n}=22)\end{array}$ & $\begin{array}{l}\text { Moderate to } \\
\text { advanced POAG } \\
(\mathrm{n}=10)\end{array}$ & $\begin{array}{l}\text { Controls } \\
(\mathrm{n}=23)\end{array}$ & $\mathrm{F}$ & $\mathrm{p}$ \\
\hline GCC Average $(\mu \mathrm{m})^{*}$ & $112.58 \pm 6.72$ & $101.32 \pm 6.42$ & $80.60 \pm 7.37$ & $119.61 \pm 5.31$ & 100.242 & $<0.001$ \\
\hline GCC Superior $(\mu \mathrm{m})^{*}$ & $112.35 \pm 6.36$ & $101.09 \pm 6.75$ & $83.20 \pm 10.09$ & $119.00 \pm 4.79$ & 79.169 & $<0.001$ \\
\hline GCC Inferior $(\mu \mathrm{m})^{*}$ & $112.69 \pm 7.06$ & $101.55 \pm 6.93$ & $77.90 \pm 6.12$ & $120.13 \pm 6.09$ & 104.158 & $<0.001$ \\
\hline GCC Minimum $(\mu \mathrm{m})^{*}$ & $69.12 \pm 8.44$ & $63.50 \pm 9.09$ & $50.90 \pm 10.17$ & $73.22 \pm 6.54$ & 18.324 & $<0.001$ \\
\hline
\end{tabular}

*mean \pm SD ANOVA, df=3; OH = ocular hypertension; POAG = primary open angle glaucoma; GCC = ganglion cell complex; TSNIT = temporal-superior-nasal-inferior-temporal sectors

for development of glaucoma (Table 5). The increasing prevalence of glaucoma was significantly related with higher IOP $(\mathrm{OR}=0.58,95 \% \mathrm{CI}$ 0.41-0.81, $\mathrm{p}=0.001)$, pathologic RNFL Average (OR=1.12, 95\%CI 1.02$1.23, \mathrm{p}=0.015)$ and RNFL Superior $(\mathrm{OR}=1.07,95 \% \mathrm{CI}$ 1.01-1.13, p=0.014). Pathologic GCC Average, Superior and Inferior also increased the prevalence of glaucoma to a significant extent $(\mathrm{OR}=1.22,95 \% \mathrm{CI} 1.07-$ $1.39, \mathrm{p}=0.002$; OR=1.24, 95\%CI 1.08-1.42, $\mathrm{p}=0.002$; and $\mathrm{OR}=1.19,95 \% \mathrm{CI} 1.06-1.34, \mathrm{p}=0.003$, respectively). Among the mentioned predictors for development of glaucoma, the highest significance was observed for IOP, GCC Average and GCC Superior.

\section{Discussion}

In the present study, we compared the glaucoma discriminating capability of RNFL and GCC parameters using SOCT Copernicus HR. Till now, many studies have been conducted regarding this problem using different $\mathrm{SD}-\mathrm{OCT}$ devices. Although results are not inter-changeable between devices, due to reported difference between structural parameters thickness at-

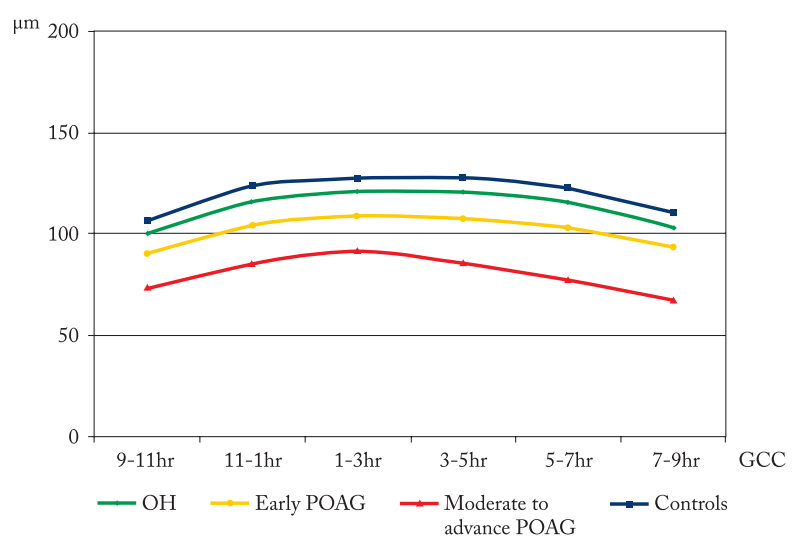

Fig. 3. Ganglion cell complex (GCC) curves in clock hour temporal-superior-nasal-inferior-temporal (TSNIT) sectors of study subjects $(N=81)$.

tributed to variation in optical properties and segmentation algorithms, studies mostly presented high diagnostic performances of these structural parameters ${ }^{23}$. The majority of studies compared mostly two groups of patients (glaucoma or early glaucoma or ocular hypertensives with healthy subjects) to determine the diagnostic ability of structural parameters using vari-

Table 4. Comparison of sensitivity, specificity and area under the ROC curve (AUC) between RNFL and GCC parameters

\begin{tabular}{|c|c|c|c|c|c|c|c|}
\hline & Sensitivity (\%) & Specificity (\%) & AUC & AUC & Sensitivity (\%) & Specificity (\%) & \\
\hline $\begin{array}{l}\text { RNFL } \\
\text { Average }\end{array}$ & 78.13 & 91.84 & 0.906 & 0.957 & 65.63 & 100.00 & $\begin{array}{l}\text { GCC } \\
\text { Average }\end{array}$ \\
\hline $\begin{array}{l}\text { RNFL } \\
\text { Superior }\end{array}$ & 65.63 & 97.96 & 0.877 & 0.955 & 71.88 & 100.00 & $\begin{array}{l}\text { GCC } \\
\text { Superior }\end{array}$ \\
\hline $\begin{array}{l}\text { RNFL } \\
\text { Inferior }\end{array}$ & 65.63 & 91.84 & 0.839 & 0.946 & 68.75 & 100.00 & $\begin{array}{l}\text { GCC } \\
\text { Inferior }\end{array}$ \\
\hline
\end{tabular}

RNFL = retinal nerve fiber layer; GCC = ganglion cell complex; $A U C=$ area under the $\mathrm{ROC}$ curve 

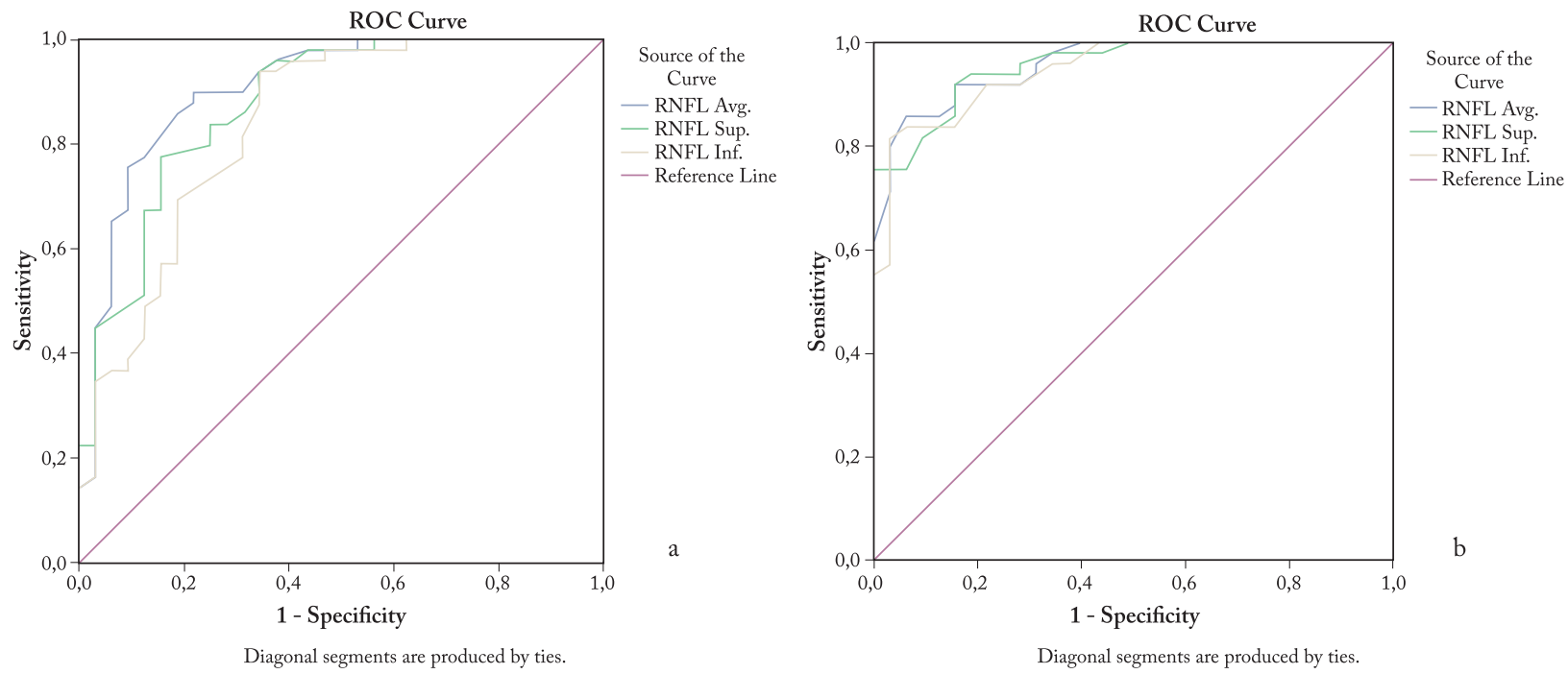

Fig. 4. (a) ROC curves for retinal nerve fiber layer (RNFL) Average, Superior and Inferior; (b) ROC curves for ganglion cell complex (GCC) Average, Superior and Inferior.

Table 5. Predictors for development of glaucoma by use of logistic regression analysis

\begin{tabular}{|l|l|l|}
\hline \multicolumn{3}{|l|}{ Glaucoma } \\
\hline Variable & OR $(95 \% \mathrm{CI})$ & $\mathrm{p}$ \\
\hline Age & $1.02(0.95-1.11)$ & 0.551 \\
BCVA & $8.27(1.26-54.33)$ & 0.312 \\
Refraction & $0.61(0.32-1.17)$ & 0.127 \\
IOP & $0.58(0.41-0.81)$ & $\mathbf{0 . 0 0 1}$ \\
MD & $0.71(0.32-1.57)$ & 0.383 \\
LV & $4.33(0.93-20.06)$ & 0.054 \\
RNFL Average & $1.12(1.02-1.23)$ & $\mathbf{0 . 0 1 5}$ \\
RNFL Temporal & $1.08(0.99-1.16)$ & 0.053 \\
RNFL Superior & $1.07(1.01-1.13)$ & $\mathbf{0 . 0 1 4}$ \\
RNFL Nasal & $1.03(0.99-1.08)$ & 0.146 \\
RNFL Inferior & $1.04(0.99-1.09)$ & 0.115 \\
GCC Average & $1.22(1.07-1.39)$ & $\mathbf{0 . 0 0 2}$ \\
GCC Superior & $1.24(1.08-1.42)$ & $\mathbf{0 . 0 0 2}$ \\
GCC Inferior & $1.19(1.06-1.34)$ & $\mathbf{0 . 0 0 3}$ \\
GCC Minimum & $1.08(0.99-1.18)$ & 0.075 \\
\hline
\end{tabular}

$\mathrm{OR}=$ odds ratio; $\mathrm{CI}$ = confidence interval; $\mathrm{BCVA}=$ best corrected visual acuity; $\mathrm{IOP}=$ intraocular pressure; $\mathrm{MD}=$ mean defect; $\mathrm{LV}=$ loss variance; $\mathrm{RNFL}=$ retinal nerve fiber layer; $\mathrm{GCC}$ = ganglion cell complex

ous SD-OCT devices. In our study, we compared healthy subjects and ocular hypertensives with patients having early, moderate and advanced glaucoma. Our study population contained a wider spectrum of patients, so it might be more applicable to clinical population.

Our results showed that all the RNFL and GCC parameters were significantly lower in patients with POAG than in those with $\mathrm{OH}$ and healthy subjects. The highest significance was observed for RNFL Average, RNFL Superior, RNFL Inferior, GCC Average and GCC Inferior. Other studies demonstrated similar structural parameters of thickness changes in glaucoma, but total values differed among SD-OCT devices. In our study, the RNFL and GCC thickness where analyzed by all sectors and through four different groups that provided detection of subtle changes. Our analysis introduced the shape of the RNFL and GCC TSNIT curves. In control and $\mathrm{OH}$ groups, RNFL TSNIT curve had a characteristic appearance with humps over the superior and inferior quadrants. In glaucoma group, TSNIT curve changed the shape, it declined and lost its humps, and in advanced stage, it became flattened. RNFL thinning, although present in all sectors, was more prominent in the inferior and superior quadrants (Fig. 2). In control and $\mathrm{OH}$ groups, TSNIT GCC curve had a shallow hump over the superonasal and inferonasal sectors, which correlated with papillomacular bundle. The curve kept the shape in glaucoma, but declined. In the area of the characteristic hump, declining and thinning was less prominent, presenting papillomacular bundle, as it is expected, and 
was longer maintained. The most prominent thinning and declining was in the inferior sector, followed by the inferotemporal, superotemporal and superior ones. Leung et al. found similar results when analyzing macular NFL (Fig. 3) ${ }^{25}$.

Diagnostic abilities of structural parameters slightly differed among the studies, even when they were obtained using the same SD-OCT device ${ }^{14,18,20}$. Some studies found similar diagnostic abilities of GCC compared to RNFL parameters in detecting early, moderate and severe glaucoma ${ }^{13-17}$. Many studies demonstrated GCC parameters to be a better tool in early glaucoma detection in comparison to $\mathrm{RNFL}^{18-20}$. Kim et al. report encouraging results in preperimetric glaucoma detection for both GCC and RNFL parameters ${ }^{17}$. GCC parameters also performed well in detection of glaucoma progression ${ }^{23}$. On the contrary, few important studies highlighted the superiority of RNFL over GCC parameters in detecting preperimetric glaucoma, early glaucoma and glaucoma progression $^{21-23}$. Most of the published reports presented slightly different but high AUCs for both RNFL (0.765-0.986) and GCC parameters (0.788-0.997).

In our study, we assessed discrimination ability of RNFL and GCC parameters between glaucomatous eyes and healthy subjects, as well as ocular hypertensives. Fine sectoral analysis of structural parameters among the four groups allowed for detection of the finest changes between the groups. Analyzing the ROC curves, all three GCC parameters (GCC Average, GCC Superior and GCC Inferior) showed better diagnostic abilities than RNFL parameters in glaucoma detection. Average RNFL was more accurate as compared to RNFL Superior and RNFL Inferior. GCC Average and GCC Superior provided the best diagnostic performance with the biggest AUCs. Our results showed $100 \%$ specificity but lower sensitivity for all GCC parameters. Even comparing to standard automated perimetry as a standard method in glaucoma diagnosis, GCC parameters had higher specificity (74.1\%, $77.8 \%, 85.2 \%$ vs. $100 \%)$ but lower sensitivity $(70 \%, 78 \%, 86 \% \text { vs. } 65.6 \%, 71.8 \%, 68.7 \%)^{26}$.

High diagnostic power of GCC parameters was additionally confirmed by logistic regression analysis, where GCC parameters proved to be better structural predictors for development of glaucoma than RNFL parameters. Thinning and changing of GCC thickness is more strongly connected with glaucoma than RNFL thickness changes. In practice, if the patient would have normal or borderline VF appearance and thinner GCC, he would be followed-up more frequently. We have to stress limitations of our study. Our study population was not completely age-matched; the more so, our results suggested that age was not a predictor of glaucoma in this study. Analysis of structural parameters is influenced by individual varieties, so the individual rate of progression in structural changes could offer even better information and results. Furthermore, there was a lack of wide normative database across the population.

\section{Conclusion}

In this study, we analyzed diagnostic accuracy of the GCC parameters compared with RNFL, using SOCT Copernicus HR. GCC parameters showed better ability to discriminate eyes with glaucoma and non-glaucomatous eyes compared to RNFL. Thinning in GCC layers was strongly connected with glaucomatous damage, indicating GCC parameters as more confident than RNFL in the complex variety of glaucoma diagnostic tests. According to our results, GCC parameters proved to be a useful tool in glaucoma diagnosis.

\section{References}

1. European Glaucoma Society. Terminology and guidelines for glaucoma. $3^{\text {rd }}$ ed. Savona: Italy; 2008.

2. Malik R, Swanson WH, Garway-Heath DF. Structure-function relationship in glaucoma: past thinking and current concepts. Clin Exp Ophthalmol. 2012;40(4):369-8. doi: 10.1111/j.1442-9071.2012.02770

3. Sommer AE, Katz J, Quigley HA, Miller NR, Robin AL, Richter RC, et al. Clinically detectable nerve fiber atrophy precedes the onset of glaucomatous field loss. Arch Ophthalmol. 1991;109(1):77-83.

4. Tan O, Huang D, Lu AT, Schuman JS, Ishikawa H, Wollstein $\mathrm{G}$, et al. Detection of macular ganglion cell loss in glaucoma by Fourier domain optical coherence tomography. Ophthalmology. 2009;116(12):2305-14. doi: 10.1016/j.ophtha.2009.05.025

5. Medeiros FA, Zangwill LM, Bowd C, Vessani RM, Susanna R Jr, Weinreb RN. Evaluation of retinal nerve fiber layer, optic nerve head, and macular thickness measurements for glaucoma detection using optical coherence tomography. Am J Ophthalmol. 2005;139(1):44-55. doi: 10.1016/j.ajo.2004.08.069

6. Zangwill LM, Bowd C, Berry CC, Williams J, Blumenthal EZ, Sánchez-Galeana CA, et al. Discriminating between normal 
and glaucomatous eyes using the Heidelberg retina tomograph, GDx nerve fiber analyzer, and optical coherence tomograph. Arch Ophthalmol. 2001;119(7):985-93.

7. Kanamori A, Nakamura M, Escano MF, Seya R, Maeda H, Negi A. Evaluation of the glaucomatous damage on retinal nerve fiber layer thickness measured by optical coherence tomography. Am J Ophthalmol. 2003;135(4):513-52.

8. Wollstein G, Schuman JS, Price LL, Aydin A, Beaton SA, Stark PC, et al. Optical coherence tomography (OCT) macular and peripapillary retinal nerve fiber layer measurements and automated visual fields. Am J Ophthalmol. 2004;138(2): 218-25. doi: 10.1016/j.ajo.2004.03.019

9. Yang Q, Reisman CA, Wang Z, Fukuma Y, Hangai M, Yoshimura N, Tomidokoro A, et al. Automated layer segmentation of macular OCT images using dual-scale gradient information. Opt Express. 2010;18(20):21293-307. doi: 10.1364/OE.18.021293

10. Prskalo MŠ, Tomić Ž, Novak-Lauš K, Prskalo Z. Correlation between macular changes in exfoliation syndrome and exfoliative glaucoma. Acta Clin Croat. 2016;55(1):87-92.

11. de Boer JF, Cense B, Park BH, Pierce MC, Tearney GJ, Bouma BE. Improved signal-to-noise ratio in spectral-domain compared with time-domain optical coherence tomography. Opt Lett. 2003;28(21):2067-9.

12. Fortune B, Cull GA, Burgoyne CF. Relative course of RNFL birefringence, RNFL thickness and retinal function changes after optic nerve transection. Invest Ophthalmol Vis Sci. 2008;49(10):4444-52. doi: 10.1167/iovs.08-2255

13. Kim NR, Lee ES, Seong GJ, Kim JH, An HG, Kim CY. Structure-function relationship and diagnostic value of macular ganglion cell complex measurement using Fourier-domain OCT in glaucoma. Inv Ophthalmol Vis Sci. 2010;51(9):4646-51. doi: 10.1167/iovs.09-5053

14. Seong M, Sung KR, Choi EH, Kang SY, Cho JW, Um TW, et al. Macular and peripapillary retinal nerve fiber layer measurements by spectral domain optical coherence tomography in normal-tension glaucoma. Inv Ophthalmol Vis Sci. 2010;51 (3):1446-52. doi: 10.1167/iovs.09-4258

15. Rolle T, Briamonte C, Curto D, Grignolo FM. Ganglion cell complex and retinal nerve fiber layer measured by Fourier-domain optical coherence tomography for early detection of structural damage in patients with preperimetric glaucoma. Clin Ophthalmol. 2011;5:961-9. doi: 10.2147/OPTH.S20249

16. Kotowski J, Folio LS, Wollstein G, Ishikawa H, Ling Y, Bilonick RA, et al. Glaucoma discrimination of segmented Cirrus spectral domain optical coherence tomography (SD-OCT) macular scans. Br J Ophthalmol. 2012;96(11):1420-5. doi: 10.1136/bjophthalmol-2011-301021
17. Kim YJ, Kang MH, Cho HY, Lim HW, Seong M. Comparative study of macular ganglion cell complex thickness measured by spectral-domain optical coherence tomography in healthy eyes, eyes with preperimetric glaucoma, and eyes with early glaucoma. Jpn J Ophthalmol. 2014;58(3):244-51. doi: 10.1007/s10384-014-0315-7

18. Naghizadeh F, Garas A, Vargha P, Holló G. Detection of early glaucomatous progression with different parameters of the RTVue optical coherence tomograph. J Glaucoma. 2014;23(4): 195-8. doi: 10.1097/IJG.0b013e31826a9707

19. Jeoung JW, Choi YJ, Park KH, Kim DM. Macular ganglion cell imaging study: glaucoma diagnostic accuracy of spectral-domain optical coherence tomography. Invest Ophthalmol Vis Sci. 2013;54(7):4422-9. doi: 10.1167/iovs.12-11273

20. Moreno PA, Konno B, Lima VC, Castro DP, Castro LC, Leite MT, et al. Spectral-domain optical coherence tomography for early glaucoma assessment: analysis of macular ganglion cell complex versus peripapillary retinal nerve fiber layer. Can J Ophthalmol. 2011;46(6):543-7. doi: 10.1016/j.jcjo.2011.09.006

21. Lisboa R, Paranhos A Jr, Weinreb RN, Zangwill LM, Leite MT, Medeiros FA. Comparison of different spectral domain OCT scanning protocols for diagnosing preperimetric glaucoma. Invest Ophthalmol Vis Sci. 2013;54(5):3417-25. doi: 10.1167/iovs.13-11676

22. Cordeiro DV, Lima VC, Castro DP, Castro LC, Pacheco MA, Lee JM, et al. Influence of optic disc size on the diagnostic performance of macular ganglion cell complex and peripapillary retinal nerve fiber layer analyses in glaucoma. Clin Ophthalmol. 2011;5:1333-7. doi: 10.2147/OPTH.S20893

23. Bussel II, Wollstein G1, Schuman JS. OCT for glaucoma diagnosis, screening and detection of glaucoma progression. $\mathrm{Br}$ J Ophthalmol. 2014;98(2):15-9. doi: 10.1136/bjophthalmol-2013-304326

24. Hodapp E, Parrish RK II, Anderson DR. Clinical decisions in glaucoma. St Louis: The CV Mosby Co., 1993; pp. 52-61.

25. Leung CK, Chan WM, Yung WH, Ng AC, Woo J, Tsang MK, et al. Comparison of macular and peripapillary measurements for the detection of glaucoma: an optical coherence tomography study. Ophthalmology. 2005;112(3):391-400. doi: 10.1016/j.ophtha.2004.10.020

26. Topouzis F, Coleman AL, Yu F, Mavroudis L, Anastasopoulos E, Koskosas A, et al. Sensitivity and specificity of the 76-suprathreshold visual field test to detect eyes with visual field defect by Humphrey threshold testing in a population-based setting: the Thessaloniki Eye Study. Am J Ophthalmol. 2004;137(3): 420-5. doi: 10.1016/j.ajo.2003.09.045 
Sažetak

\title{
USPOREDBA DEBLJINE KOMPLEKSA GANGLIJSKIH STANICA I ŽIVČANIH VLAKANA MREŽNICE U DIJAGNOSTICI GLAUKOMA
}

\author{
S. Vidas, S. Popović-Suic, K. Novak Lauš, S. Jandroković, M. Tomić, T. Jukić i M. Kalauz
}

Cilj je bio usporediti debljinu sloja živčanih vlakana mrežnice (RNFL) i kompleksa ganglijskih stanica (GCC) u bolesnika s primarnim glaukomom otvorenog kuta $(\mathrm{POAG})$, okularnom hipertenzijom $(\mathrm{OH})$ i u zdravih ispitanika te istražiti ulogu parametara GCC u dijagnostici glaukoma. Ispitanici su bili podijeljeni u četiri skupine prema Hodapp-Parrish-Andersonovoj klasifikaciji: 26 ispitanika s OH, 22 s ranim POAG-om, 10 s umjerenim do uznapredovalim POAG-om i 23 zdrava ispitanika. Svim ispitanicima je izmjerena debljina RNFL-a i GCC-a primjenom SOCT Copernicus HR. Ispitanici s POAG-om imali su značajno niže vrijednosti debljine GCC i RNFL nego ispitanici s OH i zdravi ispitanici, osobito vrijednosti prosječnog RNFL-a te RNFL-a u gornjem i donjem kvadrantu. Od svih parametara RNFL najveće područje ispod krivulje (AUC) pripadalo je prosječnom RNFL-u, 0,906. Prosječni GCC te GCC u gornjem i donjem kvadrantu imali su ukupno najveće vrijednosti AUC-a sa 100\% specifičnošću. Glavni prediktori za razvoj glaukoma su bili prosječni RNFL, RNFL u donjem kvadrantu, prosječni GCC te GCC u gornjem i donjem kvadrantu ( $\mathrm{p} 1=0,015$ i p2=0,014 prema p3=0,002, $\mathrm{p} 4=0,002$ i p5=0,003). U zaključku, parametri GCC su bolje razlikovali glaukomske od neglaukomskih bolesnika te su se pokazali kao bolji prediktori razvoja glaukoma u odnosu na parametre RNFL.

Ključne riječi: Glaukom; Živčana vlakna; Glaukom otvorenog kuta; Glaukom, primarni otvorenog kuta; Očna hipertonija; Hrvatska 